\title{
MOŽNOSTI A VYBRANÉ POSTUPY IDENTIFIKÁCIE OHROZENIA PÔDY VODNOU ERÓZIOU
}

\author{
Viera Petlušová, Peter Petluš, Erika Tobiašová, Juraj Hreško
}

\begin{abstract}
Proper identification of erosion processes is possible by a combination of the presented methods. The importance is in exact localization of areas endangered by the erosion with the possibility of designing exact anti-erosion protection. The method of visual identification, verification of erosion processes by soil probes and identification of soil organic matter and soil structure were used. Significant soil loss caused by water erosion has become a global problem. An effective solution of this problem is conditioned by the effective identification of areas under threat of water erosion, which prevails in Slovakia. The aim is to point out the need to combine methods of identification of water erosion processes in order to objectify them for the needs of elimination of water erosion in agricultural practice. For water erosion assessment we used the method of spatial extension and digitisation of surface water erosion results using aerial photographs and modelling of water erosion processes using the universal equation for calculating the loss of soil by water erosion.
\end{abstract}

Keywords: erosion process, modelling of water erosion, soil probe, soil organic matter, anti-erosion soil protection

\section{Úvod}

Ohrozenie pôdy vodnou eróziou sa stalo závažným problémom riešeným na globálnej úrovni. Spôsobuje škody súvisiace s trvalým znižovaním úrodnosti pôdy, zmenšovaním produkčných plôch pol'nohospodárskej pôdy, rozčleňovaním územia výmol'mi, vznikom spustnutých plôch a i. Dôsledkom toho môže dôjst' ku zmenám kvality vody, ovzdušia, biologickej diverzity. V podmienkach Slovenska možno procesy vodnej erózie sledovat’ aj v pahorkatinách, ktoré majú vhodné klimatické a pôdne podmienky na pol'nohospodárske využívanie. Výskum vodnej erózie bol realizovaný $\mathrm{v}$ nížinnom type pahorkatinovej krajiny. Nížinné pahorkatiny Slovenska sú najviac atakované pol’nohospodárskou činnost'ou človeka prakticky už od mladého paleolitu, čo dokumentujú mnohé archeologické výskumy. V 50. rokoch 20. storočia so zmenami socioekonomických podmienok došlo k významným zmenám hospodárenia na pôde, ktorých dôsledkom boli zmeny vel'kosti parciel. Postupne sa uplatňoval proces intenzifikácie a scel'ovania pozemkov. Menili sa formy využívania pôdy, ktoré podporovali urýchl'ovanie procesov spojených s povrchovým odtokom zrážkovej vody. Efektívne riešenie 
tohto problému je podmienené účinnou identifikáciou plôch ohrozených vodnou eróziou, ktorá v podmienkach Slovenska prevažuje.

Ciel'om je poukázat' na potrebu kombinácie metód identifikácie procesov vodnej erózie za účelom ich objektivizácie pre potreby eliminácie vodnej erózie v pol'nohospodárskej praxi.

\section{Teoreticko-metodické východiská}

Problematike erózie a degradácie pôdy boli venované početné štúdie, realizácie projektov protieróznej ochrany a tiež projekty pozemkových úprav. Erózne procesy predstavujú významne negatívny faktor spôsobujúci odnos a akumuláciu pôdnych častíc z vrchného pôdneho horizontu v pol'nohospodárskej krajine. Vrchný horizont pôdy, najviac obohatený organickým materiálom, významne podmieňujúci úrodnost' pôd, je najviac náchylným na odnos. Jeho odnos, t.j. strata je konečný a nezvratný stav, ktorý vedie k poklesom výnosov na pol'nohospodárskej pôde a k značným ekonomickým stratám, ktoré môžu mat' nie len ekonomické ale aj sociálne dôsledky. Výskumu vodnej erózie v pol'nohospodárskej krajine v podmienkach Slovenska sa venovali Zachar (1970, 1982), Fulajtár, Janský (2001), Stankoviansky (2000, 2001). Vznik vodnej erózie je podmienený okrem iného aj morfologicko-morfometrickými vlastnostami reliéfu. Vplyvom morfometrických vlastností reliéfu na prejavy vodnej erózie sa zaoberali Panagos, Borrelli et al. (2015), Kirkby, Bracken, Reaney (2002), Styk (2002). Uvedení autori poukázali na vplyv morfometrických vlastností reliéfu (sklonu územia) na vznik vodnej erózie. Tiež uvádzajú, že okrem sklonu územia má významný vplyv na eróziu využívanie krajiny. O závažnosti problematiky erózno-akumulačných procesov hovorí aj rozsah rozpracovania tejto problematiky v mnohých významných zahraničných vedeckých prácach, ktoré využívajú inovatívne informačné systémy. Jedným $\mathrm{z}$ dominantných systémov, ktorý $\mathrm{v}$ súčasnosti zohráva dôležitú úlohu pri determinácii erózno-akumulačných procesov je dial'kový prieskum Zeme. Vodná erózia sa na povrchu pôdy prejavuje vznikom odtokových dráh, ktoré majú rôzne rozmery, príp. môžu pôsobením vody vznikat' strže. Zachar (1970), Fulajtár, Janský (2001), Janeček (2008), Ward, Trimble (2004) a i. klasifikujú tieto prejavy ako plošnú a líniovú eróziu. Na rozvoj eróznych procesov na ornej pôde má významný vplyv aj činnost' človeka, ktorý ich urýchluje a podporuje tak vznik antropogénnej erózie. Fulajtár, Janský (2001) za priamu antropogénnu eróziu považujú procesy, ktoré sú priamym výsledkom l’udskej činnosti. Niektoré sú podobné prirodzeným procesom napr. závlahová erózia. Iné sú odlišné napr. orbová erózia, ktorá je najbežnejším prejavom antropogénnej erózie. Jej prítomnost' je zrejmá na svahovitých pozemkoch (Smetanová, 2011; Kollárová, 2013). Výskum eróznych procesov sa postupne zdokonal'uje. Hladajú sa nové možnosti a postupy identifikácie vodnej erózie, ktoré by bolo možné zovšeobecnit' a uplatňovat' ich v praxi. Vol'ba metód je však 
závislá od účelu výskumu a môže byt' koncipovaná tematicky aj územne. Vysoká variabilita metód výskumu erózie spôsobuje, že väššina prác má svoje špecifické zameranie (pedologické, geografické, hydrologické a i.).

Príspevok je zameraný na predstavenie možností a vybraných postupov identifikácie ohrozenia pôdy vodnou eróziou pol’nohospodárskej pôdy vybranými metódami. Niektoré výsledky boli publikované v prácach Petlušová et al. (2016, 2017).

Pri hodnotení metód identifikácie procesov vodnej erózie bola využitá metóda priestorového rozšírenia a digitalizácia plošných prejavov vodnej erózie $\mathrm{s}$ využitím leteckých snímok a modelovanie procesov vodnej erózie s využitím univerzálnej rovnice pre výpočet straty pôdy vodnou eróziou. Ďalšie metódy identifikácie boli založené na potrebe realizácie terénneho prieskumu. Využitá bola metóda vizuálnej identifikácie, overovanie eróznych procesov pôdnymi sondami a identifikácia pôdnej organickej hmoty a pôdnej štruktúry.

\section{Modelové územie}

Modelovým územím je intenzívne pol'nohospodársky využívaná pahorkatinová krajina $\mathrm{v}$ katastrálnych územiach obcí L'ubá a Belá (okres Nové Zámky) v Hronskej pahorkatine (mapa 1). Súčasný charakter využívania krajiny je výsledkom intenzifikácie pol’nohospodárstva. Prevažuje vel'kobloková orná pôda so zastúpením hnedozeme, černozeme a regozeme. Územie je súčastou Podunajskej pahorkatiny. Má charakter strednej až mierne členitej pahorkatiny s nadmorskou výškou 110 - $250 \mathrm{~m}$ n. m. Výber územia bol podmienený prítomnost'ou výrazných eróznych procesov.

Mapa 1: Vymedzenie modelového územia v rámci Slovenskej republiky Map 1: Location of model area in Slovak republic

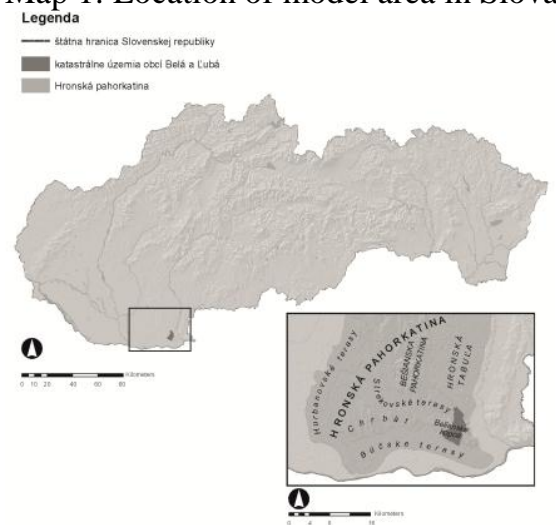

Zdroj: digitálne vrstvy Atlas krajiny SR (2012) 


\section{Priestorové rozšírenie a digitalizácia plošných prejavov eróznych procesov $s$ využitím leteckých snímok}

Priestorové rozšírenie eróznych a akumulačných areálov sa realizovalo vizuálnym hodnotením a interpretáciou leteckých snímok. Identifikácia eróznych procesov sa realizovala vizuálne na podklade čiernobielych (roky 1949 a 1970) a farebných leteckých snímok s vel'kost’ou rastra $1 \mathrm{~m}$ resp. 0,3 m (roky 2014 a 2015) zo šiestich časových období (roky 1949, 1970, 2006, 2011, 2014, 2015). Snímky pochádzajú z rôznych ročných období, čím sa čiastočne eliminoval efekt vegetačného krytu (sezónne čiastočne prekrývajúci vizuálny prejav erózie). Plošné hodnotenie kvantitatívneho zastúpenia eróznych plôch sme získali vektorizáciou svetlých amébovitých útvarov na leteckých snímkoch. Významné boli plochy, kde erózia prebiehala $\mathrm{v}$ minulosti a prebieha aj $\mathrm{v}$ súčasnosti alebo sa vyskytla len $\mathrm{v}$ minulosti alebo len $\mathrm{v}$ súčasnosti. Nazvané boli ako plochy reálne a potenciálne ohrozené vodnou eróziou (mapa 2). Plošný prejav vodnej erózie v období rokov 1949 - 2016 sa zvýšil o 130,56 ha (8,88 \%). K zväčšeniu eróznych plôch došlo zmenou využívania krajiny napr. úzkopásové políčka za zmenili na vel'koblokové polia. Plochy reálne a potenciálne ohrozené vodnou eróziou predstavovali spolu 408,44 ha $(27,78 \%)$. Takto získané plochy je možné využit' pri d’alších možnostiach zist'ovania prejavov procesov vodnej erózie. Je možné kombinovat' ich napr. so sklonitost'ou, expozíciou svahov, typom zmeny využívania územia, odnosom pôdy a pod (Petlušová et al., 2016).

$\mathrm{Z}$ výsledkov výskumu uvádzame ako príklad sklonitost'. Kombináciou reálne ohrozených plôch a sklonitosti boli identifikované plochy kde sklonitost' výrazne ovplyvňuje resp. neovplyvňuje plošné rozšírenie erózie. Sklonitost' sa hodnotila v 5 kategóriách. V kategórii 0 - $1^{\circ}$ bola erózia zastúpená na 25,44 ha $(16,9 \%)$. Sú to plochy, ktoré sa využívajú sa na pestovanie jarných aj ozimných obilnín, olejnín, strukoví a pod. V kategórii 1 - $3^{\circ}$ je erózia na ploche 66,44 ha (17,70\%). Z hl'adiska využívania krajiny sa tieto lokality využívajú prevažne ako orná pôda ale tiež trvalé trávne porasty. V kategórii sklonitosti $3-7^{\circ}$ je to 218,90 ha $(30,27 \%)$. Prevažnú čast' územia tvorí orná pôda. Za významný prvok vinohrady. V kategórii $7-12^{\circ}$ bola erózia zistená na ploche 80,69 ha $(39,83 \%)$. Vhodnost' pôdnych pomerov ale dáva možnost' vyžívat' toto územie ako ornú pôdu napriek tomu, že riziko vzniku eróznych procesov je vysoké. Podobne je to aj v kategórii sklonitosti $12^{\circ} \mathrm{a}$ viac, ktorá je zastúpená na ploche 4,22 ha $(22,40 \%)$. Z výsledkov je zrejmá závislost' medzi sklonom územia a zastúpením reálnych eróznych plôch. 
Mapa 2: Plochy ohrozené vodnou eróziou

Map 2: Areas endangered by water erosion

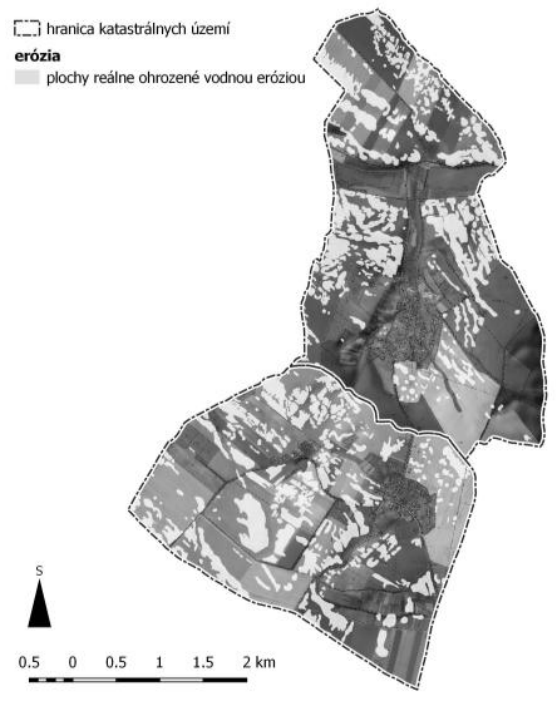

Zdroj: digitálny model terénu 10x10, Esprit s. r. o.; Základná mapa SR 1:10 000; ortofotomapa EUROSENSE, 2015

\section{Modelovanie procesov vodnej erózie}

Realizovalo sa ako výpočet potenciálnej priemernej ročnej straty pôdy a stanovenie odnosu materiálu zo svahu.

$\mathrm{Na}$ zistenie potenciálnej priemernej ročnej straty pôdy bola použitá tzv. univerzálna rovnica pre výpočet dlhodobej straty pôdy vodnou eróziou - USLE podl'a Wischmeiera a Smitha (1978). Hodnota prípustnej straty pôdy slúži na stanovenie miery erózneho ohrozenia pozemku. Je definovaná ako maximálna vel'kost' erózie pôdy, ktorá dovol'uje dlhodobo a ekonomicky dostupne udržovat' dostatočnú úroveň úrodnosti pôdy (Janeček a kol., 2012). Pri kategorizácii výpočtom získaných údajov sa vychádzalo zo 4 kategórií priemernej ročnej straty pôdy, ktoré sú uvedené v Zákone č. 220/2004 Z. z., ktorý uvádza hraničné hodnoty kategórií erodovatel'nosti pol'nohospodárskych pôd (mapa 3). Výrazné prejavy erózie boli zistené $\mathrm{v}$ stredne členitých pahorkatinových častiach územia so sklonitost'ou väčšou ako $3^{\circ}$, prevažne však tam, kde je sklonitost' územia $7-12^{\circ}$. V týchto častiach podl'a údajov získaných pri výpočtoch straty pôdy prevláda kategória 2 a 3 (stredná a vysoká strata pôdy). Územie sa dlhodobo využíva ako vel'kobloková intenzívne využívaná orná pôda. V jednej lokalite v kategórii $3 \mathrm{~s}$ vysokou stratou pôdy je v súčasnom období les. 
Pri stanovení odnosu materiálu zo svahu sa vychádzalo z metodiky Miklós, a kol. (1997). Metodika bola upravená vzhl'adom na predpoklad transportu pôdnych častíc po svahu a nie ich akumuláciu. Využité boli krivosti reliéfu. Boli vypočítané $\mathrm{v}$ prostredí geografických informačných systémov na podklade digitálneho modelu reliéfu. Odvodený bol zo základných vrstevnicových máp SR v mierke 1:10 000. Pre vertikálnu aj horizontálnu členitost' sa určili 3 kategórie: plochy konkávne, prepadnuté so spomaleným odnosom, plochy rovné, nezakrivené a plochy konvexné, vypuklé so zrýchleným odnosom. Syntézou vertikálnej a horizontálnej krivosti boli zistené základné formy reliéfu, ktoré sa považujú za rozhodujúce pri stanovení odtokových pomerov a pre naše potreby pre stanovenie potenciálneho odnosu materiálu zo svahu. Základné formy reliéfu boli spolu so sklonitost'ou územia využité pri výpočtoch odnosu materiálu zo svahov. Identifikovali sme 3 kategórie odnosu materiálu: slabý, stredne silný, silný. $\mathrm{Na}$ väčšej časti územia sú zastúpené kategórie stredne silného až silného odnosu, čo výrazne podmieňuje odnos pôdnych častíc a ich akumuláciu v konkávnych častiach územia (mapa 4).

Mapa 3: Potenciálna ročná strata pôdy Map 3: Annual average potential soil erosion

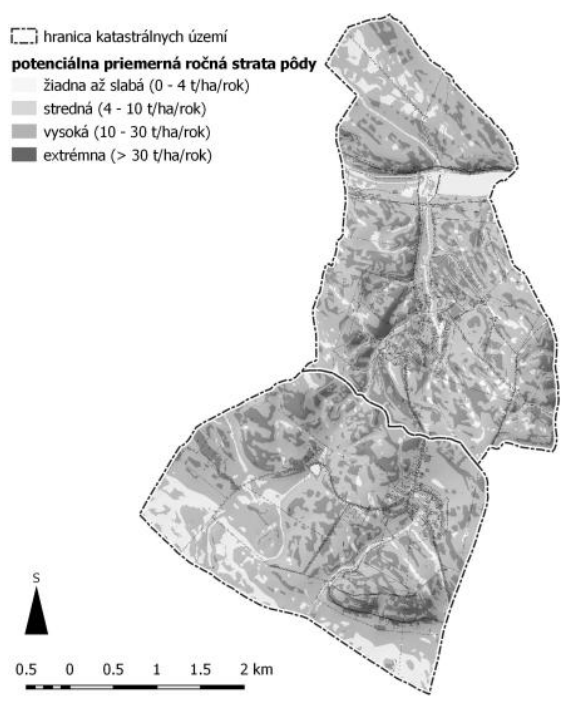

Mapa 4: Odnos materiálu so svahu Map 4: Removal of material from the slope

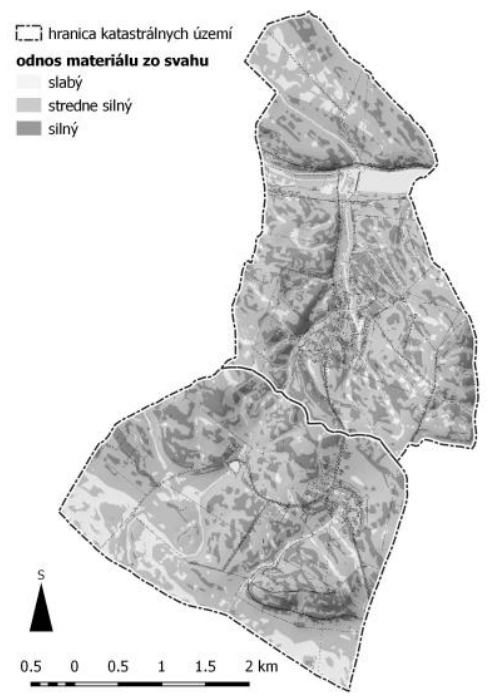

Zdroj: digitálny model terénu 10x10, Esprit s. r. o.; Základná mapa SR 1:10 000; ortofotomapa EUROSENSE, 2015 
Modelovanie procesov vodnej erózie možno považovat' za účinný spôsob ochrany pôdy pred vodnou eróziou, ktorým si užívatel' pôdy manažuje obhospodarovanie za účelom minimalizovania strát pôdnej hmoty. Na základe výskumu sa potvrdilo, že pôda podlieha eróznym procesom. V priebehu sledovaného obdobia sa plocha intenzívne pol'nohospodársky využívala. Pestovala sa repka olejná, pšenica ozimná a na susednom pôdnom celku s prejavom strednej straty pôdy kukurica siata.

\section{Identifikácia a overovanie vizuálnych eróznych procesov pomocou pôdnych sond}

Na identifikáciu bola použitá pôdna sonda Edelman s možnost'ou vŕtania do $500 \mathrm{~cm} \mathrm{~s}$ priemerom $50 \mathrm{~mm}$. Overovali sa mocnost' humusového horizontu, prítomnost' pôdnych horizontov, híbka preorávania, charakter pôdotvorného substrátu a mocnost' akumulovaného materiálu. Na základe zistených údajov sa identifikovali eróziou ohrozené pôdy (svetlé plochy) alebo zemina akumulovaná $\mathrm{v}$ konkávnych častiach svahov ako prejav transportu pôdnych častíc po svahu. Identifikácia sa realizovala 39 pôdnymi sondami. Overenie eróznych procesov pomocou pôdnych sond poukazuje, že prevažne zastúpené pôdne typy regozem, hnedozem erodovaná, černozem erodovaná, indikujú prítomnost’ erózie minimálne $\mathrm{v}$ troch štvrtinách prípadov (tab.1). Pôdne sondy poukázali aj na to, že v dolných akumulačných častiach svahov a na konvexných formách svahov s nižším sklonom sa nachádzajú naplaveniny (koluviozeme) do híbky viac ako $2 \mathrm{~m}$.

Tab. 1: Pôdne typy s prejavom erózie (E) a bez prejavu erózie pôdy $(\mathrm{N})$ Table 1: Soil types whit erosion (E) and without erosion $(\mathrm{N})$

\begin{tabular}{|c|c|c|c|c|c|}
\hline $\begin{array}{l}\text { číslo } \\
\text { sondy }\end{array}$ & klasifikácia pôdneho typu & & $\begin{array}{l}\text { číslo } \\
\text { sondy }\end{array}$ & klasifikácia pôdneho typu & \\
\hline 1 & $\begin{array}{l}\text { regozem kultizemná na } \\
\text { neogénnych sedimentoch }\end{array}$ & $\mathrm{E}$ & 27 & $\begin{array}{l}\text { černozem erodovaná na } \\
\text { spraši }\end{array}$ & $\mathrm{E}$ \\
\hline 2 & $\begin{array}{l}\text { regozem kultizemná na } \\
\text { neogénnych sedimentoch }\end{array}$ & $\mathrm{E}$ & 28 & $\begin{array}{l}\text { černozem arenická na } \\
\text { neogénnych pieskoch }\end{array}$ & $\mathrm{N}$ \\
\hline 3 & $\begin{array}{l}\text { regozem kultizemná na } \\
\text { neogénnych sedimentoch }\end{array}$ & $\mathrm{E}$ & 29 & regozem na spraši & $\mathrm{E}$ \\
\hline 4 & $\begin{array}{l}\text { hnedozem erodovaná na } \\
\text { neogénnych sedimentoch }\end{array}$ & $\mathrm{E}$ & 30 & černozem na spraši & $\mathrm{N}$ \\
\hline 5 & $\begin{array}{l}\text { černozem erodovaná na } \\
\text { neogénnych sedimentoch }\end{array}$ & $\mathrm{E}$ & 31 & $\begin{array}{l}\text { regozem kultizemná na } \\
\text { spraši }\end{array}$ & $\mathrm{E}$ \\
\hline 6 & $\begin{array}{l}\text { regozem typická na } \\
\text { neogénnych sedimentoch }\end{array}$ & $\mathrm{E}$ & 32 & $\begin{array}{l}\text { černozem erodovaná na } \\
\text { spraši }\end{array}$ & $\mathrm{E}$ \\
\hline 7 & koluviozem & $\mathrm{E}$ & 33 & $\begin{array}{l}\text { nezistený pôdny typ } \\
\text { výrazne rubifikovaný }\end{array}$ & $\mathrm{N}$ \\
\hline 8 & $\begin{array}{l}\text { černozem erodovaná na } \\
\text { sprašiach }\end{array}$ & $\mathrm{E}$ & 34 & $\begin{array}{l}\text { černozem erodovaná na } \\
\text { spraši }\end{array}$ & $\mathrm{E}$ \\
\hline
\end{tabular}




\begin{tabular}{|c|c|c|c|c|c|}
\hline 9 & $\begin{array}{l}\text { černozem kultizemná } \\
\text { karbonátová na spraši }\end{array}$ & $\mathrm{N}$ & 35 & koluviozem & $\mathrm{E}$ \\
\hline 10 & koluviozem & $\mathrm{E}$ & 36 & $\begin{array}{l}\text { nezistený pôdny typ } \\
\text { výrazne rubifikovaný na } \\
\text { spraši }\end{array}$ & $\mathrm{N}$ \\
\hline 11 & $\begin{array}{l}\text { regozem typická na } \\
\text { neogénnych pieskoch }\end{array}$ & $\mathrm{E}$ & 37 & černozem typická na spraši & $\mathrm{N}$ \\
\hline 12 & $\begin{array}{l}\text { hnedozem kultizemná na } \\
\text { odvápnených sprašiach } \\
\text { regozem na zvetralých }\end{array}$ & $\mathrm{N}$ & 38 & $\begin{array}{l}\text { černozem erodovaná na } \\
\text { spraši }\end{array}$ & $\mathrm{E}$ \\
\hline 13 & $\begin{array}{l}\text { neogénnych štrkoch } \\
\text { nespevnených }\end{array}$ & $\mathrm{E}$ & 39 & černozem typická na spraši & $\mathrm{N}$ \\
\hline 14 & $\begin{array}{l}\text { černozem typická } \\
\text { odvápnená na spraši }\end{array}$ & $\mathrm{E}$ & 40 & deluviát & $\mathrm{E}$ \\
\hline 15 & $\begin{array}{l}\text { černozem hnedozemná } \\
\text { akumulovaná }\end{array}$ & $\mathrm{E}$ & 41 & $\begin{array}{l}\text { regozem kultizemná na } \\
\text { spraši }\end{array}$ & $\mathrm{E}$ \\
\hline 16 & $\begin{array}{l}\text { regozem kultizemná na } \\
\text { spraši }\end{array}$ & $\mathrm{E}$ & 42 & deluviát & $\mathrm{E}$ \\
\hline 17 & $\begin{array}{l}\text { černozem kultizemná } \\
\text { karbonátová }\end{array}$ & $\mathrm{N}$ & 43 & regozem typická na spraši & $\mathrm{E}$ \\
\hline 18 & regozem na spraši & $\mathrm{E}$ & 44 & černozem typická & $\mathrm{N}$ \\
\hline 19 & regozem na spraši & $\mathrm{E}$ & 45 & $\begin{array}{l}\text { černozem hnedozemná na } \\
\text { spraši }\end{array}$ & $\mathrm{N}$ \\
\hline 20 & $\begin{array}{l}\text { hnedozem erodovaná } \\
\text { (rubifikovaná) na spraši }\end{array}$ & $\mathrm{E}$ & 46 & $\begin{array}{l}\text { černozem erodovaná na } \\
\text { spraši }\end{array}$ & $\mathrm{E}$ \\
\hline 21 & koluviozem & $\mathrm{E}$ & 47 & $\begin{array}{l}\text { černozem erodovaná na } \\
\text { spraši }\end{array}$ & $\mathrm{E}$ \\
\hline 22 & koluviozem & $\mathrm{E}$ & 48 & regozem na spraši & $\mathrm{E}$ \\
\hline 23 & $\begin{array}{l}\text { regozem kultizemná na } \\
\text { neogénnych sedimentoch }\end{array}$ & $\mathrm{E}$ & 49 & $\begin{array}{l}\text { regozem mycelárna } \\
\text { karbonátová }\end{array}$ & E \\
\hline 24 & $\begin{array}{l}\text { regozem kultizemná na } \\
\text { neogénnych sedimentoch }\end{array}$ & $\mathrm{E}$ & 50 & $\begin{array}{l}\text { černozem erodovaná na } \\
\text { spraši }\end{array}$ & E \\
\hline 25 & $\begin{array}{l}\text { černozem erodovaná na } \\
\text { spraši }\end{array}$ & $\mathrm{E}$ & 51 & $\begin{array}{l}\text { akumulát na neogénnych } \\
\text { štrkoch }\end{array}$ & $\mathrm{E}$ \\
\hline 26 & $\begin{array}{l}\text { černozem kultizemná na } \\
\text { spraši }\end{array}$ & $\mathrm{N}$ & & & \\
\hline
\end{tabular}

Zdroj: terénny prieskum (2015 - 2017)

\section{Identifikácia pomocou analýzy pôdnej organickej hmoty a pôdnej štruktúry}

Prejavy vodnej erózie sú nielen kvantitatívneho, ale aj kvalitatívneho charakteru. Identifikácia týchto zmien na základe vybraných parametrov pôdnej organickej hmoty (SOM) a pôdnej štruktúry odráža nielen prejavy tejto formy erózie v krajine, ale aj zmeny v produkčnej schopnosti pôd ovplyvnených vodnou eróziou (Pintaldi et al., 2018; Wang et al., 2018). Odnosom častíc z povrchového humusového horizontu, ktorý je najbohatší na organické látky, dochádza nielen $\mathrm{k}$ redukcii hrúbky tejto aktívnej časti pôdneho profilu (Conforti et al., 2013), ale aj 
k zhoršovaniu d’alších vlastností pôdy (Šarapatka et al., 2018), pretože sú v úzkom vzt’ahu s pôdnou organickou hmotou. V tejto súvislosti sa uvažuje nielen o znižovaní obsahu organického uhlíka, ale aj o jeho distribúcii v pôdnych agregátoch, čo súvisí so sekvestráciou uhlíka (Lal, 2018; Li et al., 2017). Pôdna štruktúra a pôdna organická hmota je spolu s pôdnou textúrou súčast'ou faktora erodovatel'nosti pri výpočte priemernej dlhodobej straty pôdy. Pri hodnotení prostredníctvom SOM a pôdnej štruktúry boli využité viaceré ich parametre ako celkový organický uhlík (TOC), labilný $\left(\mathrm{C}_{\mathrm{L}}\right)$ a nelabilný $\left(\mathrm{C}_{\mathrm{NL}}\right)$ uhlík, humusové látky $(\mathrm{HL})$, frakčné zloženie pôdnych agregátov, koeficient zranitel'nosti pôdnej štruktúry $\left(\mathrm{K}_{\mathrm{v}}\right)$ (Valla et al., 2000), index tvorby prísušku ( $\mathrm{I}_{\mathrm{c}}$ ) (Lal a Shukla, 2004) či kritický obsah SOM $\left(\mathrm{S}_{\mathrm{t}}\right)$ (Valla et al., 2000), na ktorých sa vplyv erózno-akumulačných procesov prejavil v plnom rozsahu. Ide o zmeny nielen v jej množstve, ale aj kvalite, resp. stabilite. Množstvo TOC, ako v pôde (tab. 2), tak aj v pôdnych agregátoch (tab. 3) sa zvyšovalo v smere z hornej časti svahu nadol, avšak kvalita humusu (tab. 2) mala opačnú tendenciu. V prípade obsahov $\mathrm{C}_{\mathrm{L}}$ (tab. 4) aj $\mathrm{C}_{\mathrm{NL}}$ (tab. 5) vo vodoodolných makro-agregátoch (WSA) bola situácia obdobná, teda ich obsahy zvyšovali v smere nadol po svahu. Obsahy organického uhlíka mali súčasne klesajúcu tendenciu od väčšej frakcie s jeho najvyšším obsahom, po najmenšiu frakciu WSA s najnižším obsahom. Odber vzoriek pôdy sa realizoval v máji 2017 (Mária dvor, Belá), októbri 2017 (nad vinohradmi, 400 m východne od kóty Dubník 208 m n. m.) a v apríli 2018 (nad vodnou nádržou Kamenný Most, Lubá).

Tab. 2: Vybrané kvantitatívne a kvalitatívne parametre pôdnej organickej hmoty Table 2: Selected quantitative and qualitative parameters of soil organic matter

\begin{tabular}{c|c|ccc|c}
\hline & $\begin{array}{c}\text { TOC } \\
\left(\mathrm{mg}^{-1} \mathrm{~kg}^{-1}\right)\end{array}$ & $\mathbf{C H L}$ & $\begin{array}{c}\mathbf{C}_{\mathbf{H K}} \\
(\%)\end{array}$ & $\mathbf{C}_{\mathbf{F K}}$ & $\mathbf{C}_{\mathbf{H K}} / \mathbf{C}_{\mathbf{F K}}$ \\
\hline R1 & 7530 & 38,11 & 26,16 & 11,95 & 1,43 \\
R2 & 10810 & 39,59 & 26,64 & 12,95 & 1,15 \\
R3 & 14570 & 43,17 & 25,26 & 17,91 & 1,13 \\
\hline
\end{tabular}

R1 - horná konvexná čast', R2 - svah, R3 - akumulačná konkávna čast'; TOC celkový organický uhlik, $C_{H L}-$ uhlik humusových látok, $C_{H K}-$ uhlik huminových kyselín, $C_{F K}-$ uhlik fulvokyselín, $C_{H K} / C_{F K}-$ pomer uhlika humínových kyselín k uhliku fulvokyselín

Tab. 3: Celkový organický uhlík vo frakciách vodoodolných makro-agregátov Table 3: Total organic carbon in the fractions of water-resistant macro-aggregates

\begin{tabular}{l|ccccccc}
\hline & $\begin{array}{c}>\mathbf{5} \\
\mathbf{m m}\end{array}$ & $\begin{array}{c}>\mathbf{3 - 5} \\
\mathbf{m m}\end{array}$ & $\begin{array}{c}>\mathbf{2 - 3} \\
\mathbf{m m}\end{array}$ & $\begin{array}{c}>\mathbf{1 - 2} \\
\mathbf{m m} \\
\left(\mathrm{mg} . \mathrm{kg}^{-1}\right)\end{array}$ & $\begin{array}{c}\mathbf{> 0 , 5 - 1} \\
\mathbf{m m}\end{array}$ & $\begin{array}{c}\mathbf{> 0 , 2 5 - 0 , 5} \\
\mathbf{m m}\end{array}$ & $\begin{array}{c}\mathbf{< 0 , 2 5} \\
\mathbf{m m}\end{array}$ \\
\hline $\mathrm{R} 1$ & 10990 & 8880 & 8860 & 11270 & 10980 & 8090 & 5580 \\
$\mathrm{R} 2$ & 13750 & 13020 & 13570 & 13080 & 11800 & 11360 & 10270 \\
$\mathrm{R} 3$ & 21010 & 17580 & 18380 & 19460 & 17950 & 16040 & 15210 \\
\hline
\end{tabular}

R1-horná konvexná čast', R2 - svah, R3-akumulačná konkávna čast' 
Tab. 4: Labilný organický uhlík oxidovatel’ný $\mathrm{KMnO}_{4}\left(\mathrm{C}_{\mathrm{L}}\right)$ vo frakciách vodoodolných makro-agregátov

Table 4: Labile organic carbon oxidized with $\mathrm{KMnO}_{4}\left(\mathrm{C}_{\mathrm{L}}\right)$ in the fractions of water-resistant macro-aggregates

\begin{tabular}{l|ccccccc}
\hline & $\begin{array}{c}>\mathbf{5} \\
\mathbf{m m}\end{array}$ & $\begin{array}{c}\mathbf{> 3 - 5} \\
\mathbf{m m}\end{array}$ & $\begin{array}{c}\mathbf{> 2 - 3} \\
\mathbf{m m}\end{array}$ & $\begin{array}{c}\mathbf{> 1 - 2} \\
\mathbf{m m} \\
\left(\mathrm{mg} . \mathrm{kg}^{-1}\right)\end{array}$ & $\begin{array}{c}\mathbf{> 0 , 5 - 1} \\
\mathbf{m m}\end{array}$ & $\begin{array}{c}\mathbf{> 0 , 2 5 - 0 , 5} \\
\mathbf{m m}\end{array}$ & $\begin{array}{c}<\mathbf{0 , 2 5} \\
\mathbf{m m}\end{array}$ \\
\hline $\mathrm{R} 1$ & 778 & 691 & 695 & 731 & 682 & 465 & 277 \\
$\mathrm{R} 2$ & 1203 & 1186 & 1070 & 1124 & 1118 & 911 & 730 \\
$\mathrm{R} 3$ & 3270 & 1593 & 2019 & 1653 & 1463 & 1683 & 987 \\
\hline
\end{tabular}

R1 - horná konvexná čast', R2 - svah, R3 - akumulačná konkávna čast'

Tab. 5: Nelabilný organický uhlík $\left(\mathrm{C}_{\mathrm{NL}}\right)$ vo frakciách vodoodolných makroagregátov

Table 5: Non-labile organic carbon $\left(\mathrm{C}_{\mathrm{NL}}\right)$ in the fractions of water-resistant macroaggregates

\begin{tabular}{l|ccccccc}
\hline & $\begin{array}{c}>\mathbf{5} \\
\mathbf{m m}\end{array}$ & $\begin{array}{c}>\mathbf{3 - 5} \\
\mathbf{m m}\end{array}$ & $\begin{array}{c}\mathbf{> 2 - 3} \\
\mathbf{m m}\end{array}$ & $\begin{array}{c}>\mathbf{1 - 2} \\
\mathbf{m m} \\
\left(\mathrm{mg}_{\mathrm{kg}} \mathbf{k}^{-1}\right)\end{array}$ & $\begin{array}{c}\mathbf{> 0 , 5 - 1} \\
\mathbf{m m}\end{array}$ & $\begin{array}{c}\mathbf{> 0 , 2 5 - 0 , 5} \\
\mathbf{m m}\end{array}$ & $\begin{array}{c}<\mathbf{0 , 2 5} \\
\mathbf{m m}\end{array}$ \\
\hline $\mathrm{R} 1$ & 10212 & 8189 & 8165 & 10539 & 10298 & 7625 & 5303 \\
$\mathrm{R} 2$ & 12547 & 11834 & 12500 & 11956 & 10682 & 10449 & 9540 \\
$\mathrm{R} 3$ & 17740 & 15987 & 16361 & 17807 & 16487 & 14357 & 14223 \\
\hline
\end{tabular}

R1-horná konvexná čast', R2 - svah, R3-akumulačná konkávna čast'

Jedným z hlavných mechanizmov sekvestrácie uhlíka je zvýšenie jeho obsahu v makro-agregátoch bohatých na uhlík (Six et al., 2002), čo predpokladá aj ich priaznivú vel'kostnú distribúciu. Zastúpenie vel'kostne priaznivejších makroagregátov preosiatych za sucha (DSA) $(1-7 \mathrm{~mm})$ sa zvyšovalo smerom nadol po svahu a naopak, obsah menších $(<1 \mathrm{~mm})$ a väčších $(>7 \mathrm{~mm})$ frakcií DSA sa znižoval (tab. 6), čo opät' poukazuje nielen na zhoršenie vlastností erodovaných vrchných častí pôdneho profilu, ale súčasne môže, podobne ako predchádzajúce parametre, identifikovat' aj eróziou postihnuté plochy.

Tab. 6. Percentuálne zastúpenie frakcií makro-agregátov preosiatych za sucha Table 6: Percentage proportion of fractions of dry-sieved macro-aggregates

\begin{tabular}{|c|c|c|c|c|c|c|c|}
\hline & $\begin{array}{l}>7 \\
\mathbf{m m}\end{array}$ & $\begin{array}{l}>5-7 \\
\mathbf{m m}\end{array}$ & $\begin{array}{l}>3-5 \\
\mathrm{~mm}\end{array}$ & $\begin{array}{l}>1-3 \\
\mathrm{~mm}\end{array}$ & $\begin{array}{c}>0,5-1 \\
\mathrm{~mm}\end{array}$ & $\begin{array}{c}>0,25-0,5 \\
\text { mm }\end{array}$ & $\begin{array}{l}<0,25 \\
\text { mm }\end{array}$ \\
\hline & \multicolumn{7}{|c|}{$(\%)$} \\
\hline R1 & 13,08 & 11,49 & 14,58 & 20,70 & 17,12 & 9,65 & 13,39 \\
\hline $\mathrm{R} 2$ & 12,36 & 16,55 & 18,23 & 22,82 & 13,74 & 7,27 & 9,04 \\
\hline R3 & 9,86 & 17,03 & 21,16 & 28,70 & 13,18 & 4,55 & 5,52 \\
\hline
\end{tabular}

R1 - horná konvexná čast', $R 2$ - svah, R3 - akumulačná konkávna čast' 
Prepojením parametrov, ktoré sú súčast'ou faktora erodovatel'nosti (SOM, pôdna štruktúra, pôdna textúra) získame d’alšie parametre, ktoré korešpondujú s prejavmi vodnej erózie. Hodnoty koeficientu zranitel'nosti pôdnej štruktúry $\left(\mathrm{K}_{\mathrm{v}}\right)$ (Valla et al., 2000) a indexu tvorby prísušku ( $\left.I_{c}\right)$ (Lal, Shukla, 2004) klesali a naopak, hodnoty kritického obsahu SOM ( $\left.\mathrm{S}_{\mathrm{t}}\right)$ (Valla et al., 2000) stúpali smerom nadol po svahu (tab. 7), na základe čoho možno za najmenej priaznivý stav považovat' opät' na plochách $\mathrm{v}$ hornej časti svahu a v podstate $\mathrm{s}$ klesajúcou tendenciou nadol.

Tab. 7. Vybrané parametre pôdnej štruktúry

Table 7: Selected parameters of soil structure

\begin{tabular}{|c|c|c|c|}
\hline & $\mathbf{K}_{\mathbf{v}}$ & $\mathbf{I}_{\mathbf{c}}$ & $\mathbf{S}_{\mathbf{t}}(\%)$ \\
\hline $\mathrm{R} 1$ & 1,441 & 1,477 & 1,706 \\
\hline $\mathrm{R} 2$ & 1,343 & 1,011 & 2,911 \\
\hline $\mathrm{R} 3$ & 1,204 & 0,689 & 3,913 \\
\hline
\end{tabular}

R1 - horná konvexná čast', R2 - svah, R3 - akumulačná konkávna čast'; Kv koeficient zranitel'nosti pôdnej štruktúry, Ic - index tvorby prísušku, St - kritický obsah pôdnej organickej hmoty

Strata pôdnej štruktúry a náchylnost' na eróziu $\left(\mathrm{S}_{\mathrm{t}}<5 \%\right)$ sa prejavila vo všetkých prípadoch a mala klesajúcu tendenciu $\mathrm{R} 1>\mathrm{R} 2>\mathrm{R} 3$.

\section{Záver}

Každá využitá identifikačná metóda ohrozenia pôdy vodnou eróziou sa preukázala ako vhodná, ale nemožno ju zovšeobecnit' a jednoznačne odporučit' pre akékol’vek hodnotené územie. Erózne procesy sú ovplyvnené špecifickými prírodnými a antropogénymi podmienkami. Uvedené metódy majú svoje pozitívne a negatívne stránky (tab. 8).

Tab. 8: Výhody a nevýhody vybraných postupov identifikácie vodnej erózie Table 8: Advantages and disadvantages of identification water erosion selected methods

\begin{tabular}{ll}
\hline \multicolumn{1}{c}{ výhody } & \multicolumn{1}{c}{ nevýhody } \\
\hline $\begin{array}{l}\text { Priestorové rozśrínie a digitalizácia plošných prejavov eróznych procesov s využitím } \\
\text { leteckých snímok }\end{array}$ & \\
\hline - možnost' vytvorenia referenčnej vrstvy & - svetlé amébovité útvarov na leteckých \\
vektorizáciou v prostredí ARC GIS, nad & snímkoch nemusia byt' eróznymi \\
ktorou sú metódou overlay vytvorené & plochami \\
priestorové jednotky, ktoré možno & - potreba overenia identifikovaných plôch \\
využit' v d'alšom hodnotiacom procese & terénnym prieskumom \\
- vytypovanie eróznych plôch, ich & \\
lokalizácia pred terénnym prieskumom & \\
\hline
\end{tabular}




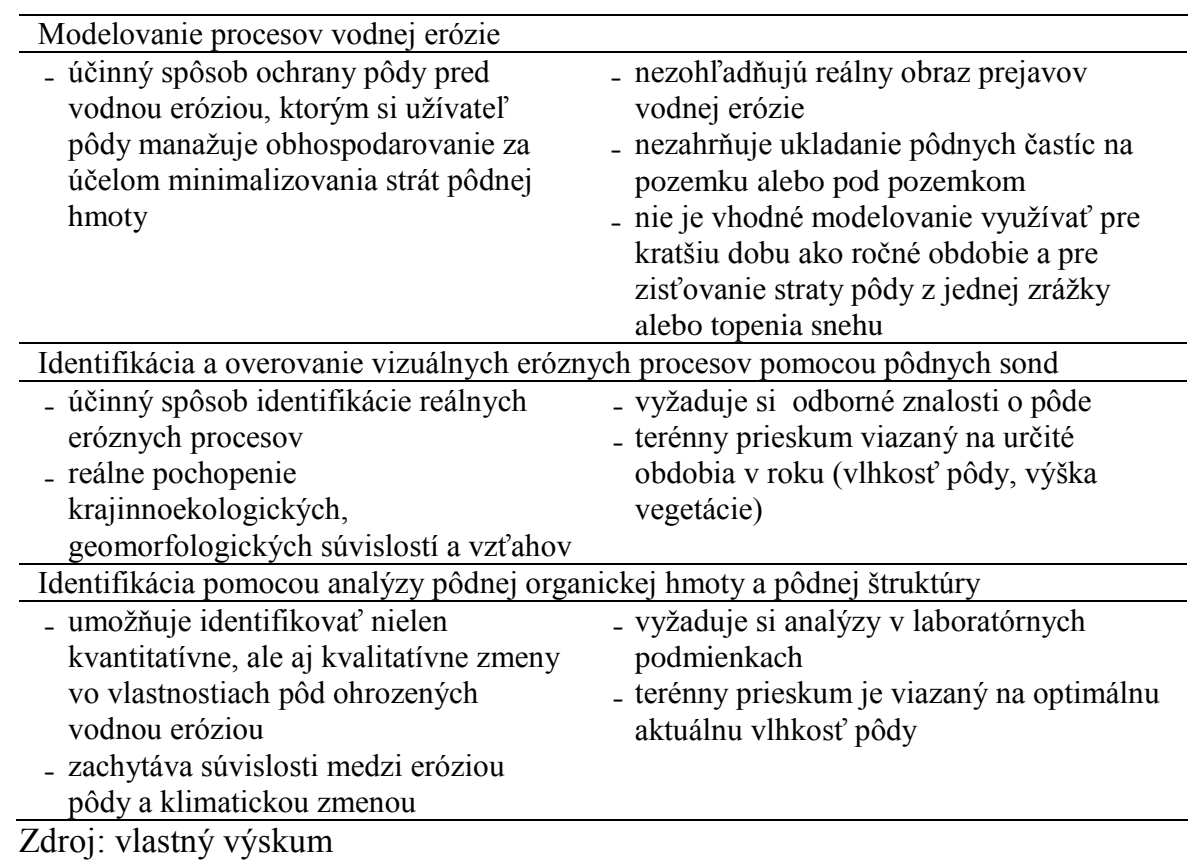

Účelná identifikácia eróznych procesov je možná kombináciou predstavených metód a postupov, ktorej bude predchádzat' podrobná analýza geologicko-geomorfologických faktorov a pedologicko-geografických faktorov. Významným krokom pri identifikácii eróznych procesov je analýza využívania krajiny vo viacerých časových horizontoch. Na jej základe možno predpokladat' či $\mathrm{v}$ území môže potenciálne dochádzat' $\mathrm{k}$ rozvoju eróznych procesov alebo $\mathrm{k}$ ich eliminácii. $\mathrm{Na}$ základe podrobných analýz je možné vybrat' si kombináciu vhodných metód určených na identifikáciu vodnej erózie. Význam kombinácie rôznych postupov spočíva $\mathrm{v}$ presnej lokalizácii eróziou ohrozených plôch $\mathrm{s}$ možnost'ou návrhu presnej protieróznej ochrany.

\section{Pod'akovanie}

Táto práca bola podporovaná Agentúrou na podporu výskumu a vývoja (č. APVV17-0377 Hodnotenie novodobých zmien a vývojových trendov polnohospodárskej krajiny Slovenska).

\section{Literatúra}

CONFORTI, M. - BUTTAFUOCO, G. - LEONE, A. P. - AUCELli, P. P. C. - 
ROBUSTELLI, G. - SCARCIGLIA, F. 2013. Studying the relationship between water-induced soil erosion and soil organic matter using Vis-NIR spectroscopy and geomorphological analysis: A case study in southern Italy. In Catena. vol. 110, pp. 44-58.

FULAJTÁR, E. - JANSKÝ, L. 2001. Vodná erózia pôdy a protierózna ochrana. Bratislava: VÚPOP, 2001. 310 s. ISBN 80-85361-85-X.

JANEČEK, M. a kol. 2012. Ochrana zemědělské půdy před erozí. Metodika. Praha: ČZU FŽP, 2012. 113 s.

JANEČEK, M. a kol. 2008. Základy erodologie. Praha: UT FŽP ČZU, Powerprint s. r. o, 2008. 172 s. ISBN 978-80-213-1842-7.

KIRKBY, M. - BRACKEN, L. - REANEY S. 2002. The influence of land use, soils and topography on the delivery of hillslope runoff to channels in SE Spain. In Earth Surface Processes and Landforms. vol. 27, pp. 1459-1473.

KOLLÁROVÁ, M. 2013. Indikátory erózie pôdy a zmena vlastností erodovaných pôd sprašových pahorkatín. In Klikušovská, Z., Sviček, M. (eds.) Environmentálne indexy, agroenvironmentálne opatrenia a ekosystémové služby v krajine. Zborník z vedeckého seminára. Bratislava: VÚPOP, 2013. s. 21-28.

LAL, R. - SHUKLA, M. K. 2004. Principles of soil physics. New York: Marcel Dekker, 2004.

LAL, R. 2018. Accelerated Soil erosion as a source of atmospheric $\mathrm{CO}_{2}$. In Soil and Tillage Research. (in press)

LI, Z. - LIU, CH. - DONG, Y. - CHANG, X. - NIE, X. - LIU, L. - XIAO, H. LU, Y. - ZENG, G. 2017. Response of soil organic carbon and nitrogen stocks to soil erosion and land use types in the Loess hilly-gully region of China. In Soil and Tillage Research. vol. 166, pp. 1-9.

MIKLÓS, L. - KRCHO, J. - HRNČIAROVÁ, T. - MATEČNÝ, I. - KOZOVÁ, M. 1997. Morfometrické ukazovatele reliéfu a ich účelnost' interpretácie pre plánovacie procesy. Nadácia katedry UNESCO pre ekologické vedomie, 1997. ISBN 80-967351-5-2.

PANAGOS, P. - BORRELLI, P. - POESEN, J. - BALLABIO, C. - LUGATO, E. - MEUSBURGER, K. - MONTANARELLA, L. - ALEWELL, C. 2015. The new assessment of soil loss by water erosion in Europe. In Environmental Science and Policy. vol. 54, pp. 438-447.

PETLUŠOVÁ, V. - PETLUŠ, P. - HREŠKO, J. 2016. Identifikácia procesov vodnej erózie v pol'nohospodárskej krajine. Nitra: UKF, 2016. 98 s. ISBN 97880-558-1118-5.

PETLUŠOVÁ, V. - PETLUŠ, P. - HREŠKO, J. 2017. Vplyv zmien využívania krajiny na eróziu pôdy $\mathrm{v}$ katastrálnych územiach L'ubá a Belá (Hronská pahorkatina). In Geograficky časopis. ISSN 0016-7193, 2017, roč. 69, č. 3, s. 245-262. 
PINTALDI, E. - D'AMICO, M. E. - STANCHI, S. - CATONI, M. - FREPPAZ, M. - BONIFACIO, E. 2018. Humus forms affect soil susceptibility to water erosion in the Western Italian Alps. In Applied Soil Ecology. vol. 123, pp. 478483.

SIX, J. - CALLEWAERT, P. - LENDERS, S. - DE GRYZE, S. - MORRIS, S. J. - GREGORICH, E. G. - PAUL, E. A. - PAUSTIAN, K. 2002. Measuring and understanding carbon storage in afforested soils by physical fractionation. In Soil Science Society of America Journal. vol. 66, no. 6, pp. 1981-1987.

SMETANOVÁ, A. 2011. Vplyv pol’nohospodárskej aktivity na reliéf nížinných sprašových pahorkatín (prehl'ad doterajších výskumov). In Acta Geographica Universitatis Comenianae. roč. 55, č. 2, s. 265-281.

STANKOVIANSKY, M. 2000. Differentiated geomorphic effect of gully erosion due to large scale land use changes. In Balteanu, D., Ielenicz, M., Popescu, N., (eds.) Geomorphology of the Carpatho-Balcan Region. Proceedings of the Carpatho-Balcan Conference, Baile Herculane, Orsova, Drobeta Turnu Severin, Romania, October 11-17, 1998. Bucuresti: CORINT, pp. 187-200.

STANKOVIANSKY, M. 2001. Erózia z orania a jej geomrofologický efekt s osobitým zretel'om na Myjavsko - bielokarpatskú oblast'. In Geografický časopis. ISSN 0016-7193, 2001, roč. 53, č. 2, s. 95-110.

STYK, J. 2002. Monitoring vplyvu vodnej erózie na zmeny vybraných vlastností pôd. In Kobza, J. (ed.) Monitoring pôd SR. Aktuálny stav a vývoj monitoringu pôd. Výsledky. z Čiastkového monitorovacieho systému - Pôda za obdobie 1997 - 2001, 2. Bratislava : VÚPOP, 2002, s. 142-159.

ŠARAPATKA, B. - CAP, L. - BILA, P. 2018. The varying effect of water erosion on chemical and biochemical soil properties in different parts of Chernozem slopes. In Geoderma, vol. 314, pp. 20-26.

VALLA M. - KOZÁK J. - ONDRÁČEK V. 2000. Vulnerability of aggregates separated from selected anthorsols developed on reclaimed dumpsites. In Rostlinná výroba. roč. 46, č. 12, s. 563-568.

WANG, Y. - RAN, L. - FANG, N. - SHI, Z._2018. Aggregate stability and associated organic carbon and nitrogen as affected by soil erosion and vegetation rehabilitation on the Loess Plateau. In Catena. vol. 167, pp. 257265.

WARD, A. D. - TRIMBLE, S. W. 2004. Environmental hydrology. 2-nd Edition. London: Lewis Publishers. 475 p. ISBN 1-56670-616-5.

WISCHMEIER, W. H. - SMITH, D. D. 1978. Predicting rainfall erosion losses. Maryland: SEA USDA Hystaville, 1978. 58 p.

ZACHAR, D. 1970. Erózia pôdy. Bratislava: SAV, 1970. $527 \mathrm{~s}$.

ZACHAR, D. 1982. Soil erosion. New York: Elsevier, 1982. 548 p.

ZÁKON č. 220/2004 Z. z. o ochrane a využívaní pol'nohospodárskej pôdy a o zmene zákona č. $245 / 2003$ Z. z. o integrovanej prevencii a kontrole znečist'ovania životného prostredia a o zmene a doplnení niektorých zákonov. 


\section{OPTIONS AND SELECTED METHODS OF IDENTIFICATION OF SOIL RISK BY WATER EROSION}

\section{Summary}

Soil changes related to erosion are reflected in the ability of soil to perform these functions. Significant soil loss caused by water erosion has become a global problem. An effective solution of this problem is conditioned by the effective identification of areas under threat of water erosion, which prevails in Slovakia. An object of research was upland. The uplands in Slovakia have suitable climatic and edaphic conditions for agricultural land use. The uplands in the Slovak lowland were intensively used by agricultural practices. The process of intensification and land unification took place. Land use types contributing to faster surface runoff of the rainwater were widely implemented.

The aim is to point out the need to combine methods of identification of water erosion processes in order to objectify them for the needs of elimination of water erosion in agricultural practice.

Our model area is intensively managed agricultural land and lies within the upland areas of Lubá and Belá administration boundaries. Its current land use character is the result of agricultural intensification. Large scale arable land with cambisols, regosols and mollic soils prevail. The area is part of Podunajska pahorkatina upland. The segmentation of the landscape has moderate to low character with altitudes from $110-250$ meters above the sea level. The selection of the area was determined by presence of significant erosion processes.

For water erosion assessment we used the method of spatial extension and digitisation of surface water erosion results using aerial photographs and modelling of water erosion processes using the universal equation for calculating the loss of soil by water erosion. Other methods of identification were based on the need for implementation of field research. The method of visual identification, verification of erosion processes by soil probes and identification of soil organic matter and soil structure were used.

Spatial extension and digitisation of surface water erosion results using aerial photographs. The identification of erosion processes was performed visually on the basis of aerial images from the 6 time periods (years 1949, 1970, 2006, $2011,2014,2015)$. The photographs come from different seasons, partially eliminating the effect of the vegetation cover (seasonal overlapping of visual evidence of erosion). The spatial evaluation of the quantitative representation of erosive areas was obtained by vectorizing the bright amoebae formations on aerial photographs. Surface water erosion results increased by 130,56 ha $(8,88 \%)$ in the period 1949 - 2016. Enlargement of erosive areas was caused by land use changes, the small scale fields turned into large scale fields. Real and potentially threatened areas by water erosion occupied 408.44 ha $(27.78 \%)$. 
Modelling of water erosion processes. We used the universal equation for the calculation of long-term soil loss by water erosion - USLE according to Wischmeier and Smith (1978). Categorization of the calculated results was based on 4 categories of average annual soil loss, which are stated in the Act no. 220/2004 Coll. Significant signs of erosion have been found in moderately hilly areas with a slope greater than $3^{\circ}$, but mostly where the slope of the area is $7-12^{\circ}$. This area is for long-term intensively used as large-scale arable land.

Visual identification and verification of erosion processes by soil probes. For identification we used soil probe Edelman. The thickness of the humus horizon, the presence of soil horizons, the depth of the ploughing, the type of the parent material and the thickness of the accumulated material have been verified. Based on collected data, we identified erosion endangered soils (bright patches) or accumulated soil in concave parts of slopes. Identification was realized through 39 soil probes. Verification of erosion processes using soil probes indicates that predominantly represented soil types of regosol, brown earth eroded, chernozem eroded indicate the presence of erosion in at least three quarters of cases.

Identification of soil organic matter and soil structure. The proof of water erosion has not only of the quantitative, but also qualitative character. Removing of the particles from the surface humus horizon, cause not only the reduction of thickness of this active part of soil profile, but also worsening of the other soil properties, because they are in a close relation to soil organic matter. In this context, it is necessary to consider not only the decreasing of total organic carbon, but also its distribution in the soil aggregates that is in a close relation to carbon sequestration. The soil structure and soil organic matter are together with the soil texture a part of erodibility factor, which is a part of universal soil loss equation for the calculation of average long-time soil loss. The erosion-accumulation processes reflected on the parameters of soil organic matter and soil structure in a full extent. Carbon quantity and its fractions both in the soil and in soil aggregates increase from the top of the slope downwards, however the quality of humus has an opposite tendency. This shows on the removing mainly the fresh sources of organic matter that are removed before their stabilization in the soil, into the lower sites, which results in a decreasing of the productive ability of the areas that are affected by removing of these particles and simultaneously it inhibits the carbon stabilization, which causes its lower sequestration in the soil, and thus higher losses not only the mechanical (erosion), but also biological (losses in the form of $\mathrm{CO}_{2}$ into the atmosphere) character.

Each identification method has proven to be appropriate but can not be generalized and explicitly recommended for every study area. Erosion processes are influenced by specific natural and anthropogenic conditions. The methods mentioned have both positive and negative sides. Proper identification of erosion processes is possible by a combination of the presented methods. The importance is in exact localization of areas endangered by the erosion with the possibility of designing exact anti-erosion protection. 


\section{Ing. Viera Petlušová, PhD.}

Katedra ekológie a environmentalistiky FPV UKF v Nitre

Trieda A. Hlinku 1, 94974 Nitra

E-mail: vpetlusova@ukf.sk

\section{RNDr. Peter Petluš, PhD.}

Katedra ekológie a environmentalistiky FPV UKF v Nitre Trieda A. Hlinku 1, 94974 Nitra

E-mail: ppetlus@ukf.sk

Doc. Ing. Erika Tobiašová, PhD.

Katedra pedológie a geológie FAPZ

Slovenská pol’nohospodárska univerzita v Nitre

Trieda A. Hlinu 2, 94976 Nitra

E-mail: erika.tobiasova@uniag.sk

\section{Prof. RNDr. Juraj Hreško, PhD.}

Katedra ekológie a environmentalistiky FPV UKF v Nitre

Trieda A. Hlinku 1, 94974 Nitra

E-mail: jhresko@ukf.sk 